Dragan JOCIĆ*

Predsednik Apelacionog suda u Nišu

Sudija Vrhovnog kasacionog suda
Pregledni naučni rad

UDK: 343.261(497.11)

343.292/.293(497.11)

Primljeno: 10. mart 2021.

Prihvaćeno: 31. mart 2021.

https://doi: $10.47152 /$ rkkp.59.1.7

\title{
PRILOG RASPRAVI O KAZNI DOŽIVOTNOG ZATVORA I MEĐUNARODNIM PRAVNIM STANDARDIMA
}

Parcijalne izmene krivičnog zakonodavstva već duže izazivaju polemiku stručne javnosti. Po pravilu njima se remeti krivično zakonodavstvo koje treba, i moralo bi biti, sistem usuglašen pre svega sa samim sobom. Reakcija stručne javnosti uzrokovana je izostankom javnih rasprava, koje bi morale, ne samo prethoditi izmenama, već biti i uvažene. Predmet rada je kritički osvrt na predlog mogućih načina prevazilaženja zakonodavnih propusta povezanih sa kaznom doživotnog zatvora za dela za koja je isključen uslovni otpust. Takođe i sa zatvorskim kaznama za krivična dela za koja je uslovni otpust isključen. Namera je da se podstakne stručna javnost na pronalaženje najboljih rešenja za prevazilaženje krivičnopravno neodržive zabrane uslovnog otpusta osuđenih na kazne doživotnog zatvora bez prava na uslovni otpust. Autor ocenjuje da pomilovanje, u našem takonodavstvu, ne predstavlja delotvoran pravni lek, pa ni alternativu uslovnom otpustu.

Ključne reči: doživotni zatvor, uslovni otpust, zahtev za vanredno ublažavanje kazne, pomilovanje.

e-mail: dragan.jocic@ni.ap.sud.rs 


\section{Osnov za raspravu}

Srpsko udruženje za krivičnopravnu teoriju i praksu i Institut za kriminološka i sociološka istraživanja, u saradnji sa Ministarstvom pravde Republike Srbije, uz podršku MDTF - JSS organizovao je ekspertski sastanak čija tema je „kazna doživotnog zatvora i međunarodni pravni standardi”. Organizatori su, uz poziv, predložili usvajanje sledećih zaključaka:

Predviđanje kazne doživotnog zatvora u nacionalnom krivičnom zakonodavstvu načelno nije u suprotnosti sa članom 3 Evropske konvencije o zaštiti ljudskih prava i osnovnih sloboda, ni praksom Evropskog suda za ljudska prava.

Prema relevantnim međunarodnim pravnim standardima i praksi ECHR ${ }^{1}$ države u čijem krivičnom zakonodavstvu je predviđena kazna doživotnog zatvora treba da predvide instrumente kojima se pruža mogućnost svakom licu osuđenom na kaznu doživotnog zatvora da bude pušteno na slobodu posle određenog vremena provedenog u kazneno popravnoj ustanovi i ispunjenja drugih zakonom predviđenih uslova, unapred poznatih osuđenom licu i zasnovanih na penološkim razlozima, o čijoj se ispunjenosti odlučuje u pravičnom postupku.

U važećem tekstu Krivičnog zakonika nisu predviđeni krivičnopravni instrumenti koji bi dali mogućnost svakom licu osuđenom na kaznu doživotnog zatvora za sva dela za koja se ona može izreći (odnosno pojedine njihove oblike) da, ispunjenjem određenih zakonom predviđenih uslova, bude pušteno na slobodu posle određenog vremena provedenog u ustanovi za izvršenje krivičnih sankcija.

Učesnici ekspertskog sastanka su saglasni sa stavom iznetim u izveštaju eksperta prof. Dr Vida Jakulina da su dva moguća načina za usaglašavanje odredaba Krivičnog zakonika o kazni doživotnog zatvora sa međunarodnim pravnim standardima, članom 3 Evropske konvencije o zaštiti ljudskih prava i osnovnih sloboda i sudskom praksom ESLjP po ovom pitanju i to:

a) Izmene i dopune Krivičnog zakonika s ciljem davanja mogućnosti svakom licu osuđenom na kaznu doživotnog zatvora da pokrene postupak puštanja na uslovni otpust nakon isteka vremena utvrđenog u Krivičnom zakoniku, i preciziranje objektivnih kriterijuma i odgovarajućih proceduralnih garancija za adekvatno donošenje odluke po podnesenoj molbi, uslova pod kojima se osuđeno lice pušta na uslovni otpust i nepoštovanja uslova pod kojima je pušten na uslovni otpust.

b) Zadržati postojeće odredbe Krivičnog zakonika o kazni doživotnog zatvora ali izvršiti izmene i dopune Zakonika o krivičnom postupku s ciljem uvođenja novog posebnog vanrednog pravnog leka - Zahteva za vanredno ublažavanje

1 Evropski sud za ljudska prava 
kazne kao procesnog mehanizma koji omogućava naknadno preispitivanje izrečene kazne doživotnog zatvora, u kojem bi kao jedan od osnova za mogućnost njegovog ulaganja bio i penološki razlog, odnosno već postignuta svrha kažnjavanja u toku izdržavanja izrečene kazne doživotnog zatvora - uz konkretizaciju i drugih pitanja ovog vanrednog pravnog leka (tj. nemogućnost podnošenja zahteva po osnovu procene o već postignutoj svrsi kažnjavanja pre dvadeset pet godina izdržane kazne doživotnog zatvora).

Zaključci su preneti u celini, pošto su osnov polemike koja sledi.

\section{O zakonodavnim rešenjima u našem zakonodavstvu}

Krivični zakonik iz 1951. godine nije predviđao kaznu doživotnog zatvora kao samostalnu kaznu, već je članom 29 bilo određeno da se umesto smrtne kazne predviđene zakonikom može izreći strogi zatvor u doživotnom trajanju. Osuđenik koji je umesto na smrtnu kaznu (zamenom iste) osuđen na kaznu doživotnog strogog zatvora mogao se uslovno otpustiti ukoliko je izdržao 15 godina strogog zatvora a uslov otpusta je trajao 10 godina. Izmenama iz 1959. godine Krivični zakonik potpuno briše kaznu doživotnog zatvora, pa i mogućnost zamene smrtne kazne kaznom doživotnog zatvora, već se smrtna kazna mogla zameniti maksimalnom zatvorskom kaznom u trajanju od 20 godina. Kasnijim izmenama, do izmena u 2019. godini, nije bila predviđena kazna doživotnog zatvora.

Izmenama i dopunama Krivičnog zakonika od 21.5.2019. godine, koje su stupile na pravnu snagu 1.12.2019. godine, članom 43 stav 1 uvedena je potpuno nova kazna, kazna doživotnog zatvora, ali je članom 44a propisano i ograničenje za njeno izricanje, odnosno da se ne može izreći učiniocima mlađim od 21 godine, niti u slučajevima kada zakon predviđa da se kazna može ublažiti ili kada postoji neki od osnova za oslobođenje od kazne. Članom 46 stav $2 \mathrm{KZ}$ propisano je da se osuđeni na ovu kaznu može uslovno otpustiti ako je izdržao najmanje 27 godina zatvora a stavom 5 da sud ne može uslovno otpustiti osuđenog za krivična dela: teško ubistvo (član 114 stav 1 tačka 9), silovanje (član 178 stav 4), obljuba nad nemoćnim licem (član 179 stav 3), obljuba sa detetom (član 180 stav 3) i obljuba zloupotrebom položaja (član 181 stav 5) KZ.

„Visina zaprećenih kazni za pojedine oblike krivičnih dela, ili teških dela kao posebno predviđenih, morala bi da prati gradaciju dela po težini. Posebno kada se radi o teškim delima, za koja su zaprećene najteže kazne. Dobar primer je krivično delo teškog ubistva, koje je zbog svoje težine i zaprećene kazne, iz ranijeg kvalifikovanog oblika ubistva izdvojeno u posebno delo. Međutim zakonodavac izmenama koje su stupile na snagu 1.12.2019. godine odstupa od prethodnog, 
tako što za kvalifikovane oblike osnovnih krivičnih dela iz članova 392 stav 3; 178 stav 4; 179 stav 3; 180 stav 3 i 181 stav 5 KZ predviđa najtežu kaznu doživotnog zatvora. Pobrojana su samo dela kod kojih je kazna doživotnog zatvora propisana za kvalifikovane oblike dela. Propisivanje najteže zakonom predviđene kazne za kvalifikovane oblike osnovnih dela gotovo da nije poznato u uporednom pravu. Zaprećena najteža kazna je dovoljan razlog da nametne potrebu izdvajanja kvalifikovanih oblika krivičnih dela, za koja je ta kazna zaprećena, u posebna dela ili jedno delo koje bi obuhvatilo teške slučajeve pobrojanih dela" (Jocić, 2020). Tako je postupljeno kod propisivanja krivičnih dela: teška dela protiv zdravlja ljudi, teška dela protiv opšte sigurnosti, teška dela protiv bezbednosti javnog saobraćaja.

Pored ove pravne manjkavosti još je problematičnija odredba člana 46 stav $5 \mathrm{KZ}$ odnosno zabrana uslovnog otpusta za krivična dela pobrojana u ovoj odredbi. Često se zanemaruje da se zabrana ne odnosi samo na kaznu doživotnog zatvora, već i na kazne zatvora izrečene za ova krivična dela. Zato što posebnu pažnju zaslužuje kada je za neko od ovih dela izrečena kazna doživotnog zatvora. Potpuno je opravdana teza da kazna doživotnog zatvora nije samo nova kazna (s obzirom da je u našem pravnom sistemu nije bilo 60 godina) već nov penološki institut. Svrhu propisane kazne doživotnog zatvora i zabrane uslovnog otpusta za pobrojana krivična dela, nemoguće je dovesti u korelaciju sa članom 2 Zakona o izvršenju krivičnih sankcija kojim je propisano da se izvršenjem krivičnih sankcija ostvaruje opšta i individualna svrha njihovog izricanja u cilju uspešne reintegracije osuđenih u društvo, jer u ovim slučajevima reintegracije u društvo nema.

Struka je bila gotovo jednoglasna da su izmene $\mathrm{KZ}$ u ovom delu neustavne kao i da su suprotne ratifikovanim međunarodnim konvencijama i opšteusvojenim međunarodnim standardima. Usvojene izmene $\mathrm{KZ}$ i reakcija struke ocenjene su kao razgovor gluvih. Autor je bio član komisije za prethodnu izmenu KZ. Održan je pripremni sastanak komisije na kojem nam je profesor pravnog fakulteta, predsednik komisije, objasnio da su izmene neophodne radi usklađivanja sa međunarodnim konvencijama i preporukama i pobrojao više desetina istih. Sledila je priča o predstojećem radu komisije. Međutim, ono što je usledilo je da više ni jedan jedini sastanak komisije nije održan ali je predlog izmena osvanuo pa potom i usvojen u Skupštini. Stoga se autorstvo izmenjenih odredaba KZ nije moglo pripisati zakonodavnoj komisiji. Ostalo je nepoznato ko je njihov autor. Na osnovu razgovora sa pojedinim članovima poslednje komisije za izmenu $\mathrm{KZ}$ i na osnovu oglašavanja člana komisije u sredstvima javnog informisanja ni ovoga puta nije bilo suštinski drugačije. Komisija se doduše sastala dva puta. Na tekst predloženih izmena KZ članovi komisije su dostavili pisane primedbe i 
predloge (pa i u odnosu na zabranu uslovnog otpusta za navedena krivična dela) ali u konačnom predlogu izmena Zakonika, ni jedna nije uvažena. Predlog izmena KZ nije dostavljen ni jednom sudu, pa ni Vrhovnom kasacionom sudu, ni jednom tužilaštvu, ni advokatskoj komori niti pravnim fakultetima. Stoga je ocena da je reakcija struke zakasnela potpuno osnovana ali je osnovana i ocena da struka nije ni bila u prilici da pravovremeno reaguje.

Međutim, istovetno zakonodavno rešenje je bilo sadržano u Nacrtu izmena i dopuna Krivičnog zakonika 2015. godine. Takvom zakonodavnom rešenju se Vrhovni kasacioni sud protivio navodeći: ,ako maksimalna kazna zatvora ostane zatvor od 20 godina, a uvede se doživotni zatvor kao najteža kazna, može se realno očekivati da će se sudovi teže opredeljivati za doživotni zatvor, obzirom da je smanjena mogućnost individualizacije kazne, jer između kazne zatvora od 20 godina i doživotnog zatvora sud nema mogućnosti da odmeri kaznu koja će biti duža od 20 godina, ali ne takva da bude doživotni zatvor" (Bilten Vrhovnog kasacionog suda, 2015). Nesumnjivo da je predlagaču ovaj stav morao biti poznat.

Nasuprot ovome u obrazloženju Predloga o izmenama i dopunama 2019. godine se navodi samo „u skladu sa inicijativom Fondacije „Tijana Jurić” predviđeno je da sud ne može uslovno otpustiti osuđenog za krivična dela određena tom inicijativom" (Dimovski, 2019:99). Utisak je da je navedeno obrazloženje istovremeno stručni i vrednosni sud predloženih izmena.

\section{Povod ekspertskom sastanku}

Održani ekspertski sastanak je signal mogućih, novih izmena KZ, odnosno izmena izmenjenog. Možda je već vreme za samoinicijativno otvaranje javnih rasprava o mogućim izmenama jer, iskustveno, nema garancija da će, ukoliko do izmena dođe, istima prethoditi javna rasprava. Van sumnje je tačka 1 zaključka da kazna doživotnog zatvora u nacionalnom zakonodavstvu načelno nije u suprotnosti sa članom 3 Evropske konvencije o zaštiti ljudskih prava i osnovnih sloboda. Sporna je usklađenost pre svega kazne doživotnog zavora (ali i zatvorskih kazi) sa zabranom uslovnog otpusta osuđenih za krivična dela pobrojana u članu 46 stav $5 \mathrm{KZ}$, sa odgovarajućim međunarodnim standardima.

Moguće rešenje, predloženo pod tačkom $4 b$ zaključaka je neprihvatljivo, držeći se predložene formulacije, iz sledećih razloga:

1) Uvođenje novog pravnog leka: zahteva za vanredno ublažavanje kazne predstavljalo bi zakonodavni ping pong. Zahtev za vanredno ublažavanje kazne 
smo već imali u našem zakonodavstvu sa oznakom predmeta - KZU, prema sudskom poslovniku. Zato se ne bi radilo o „novom” pravnom leku već o vraćanju starog pravnog leka. Zakonodavno brisanje jednog pravnog leka pa potom njegovo ponovno uvođenje predstavlja nedovoljnu promišljenost zakonodavca.

2) Isti institut, vanredno ublažavanje kazne, već postoji sada u članu 473 stav 1 tačka 6 ZKP pa ni po ovom osnovu ne bi bio nov pravni lek. Ukoliko bismo ga uveli kao „nov” onda bi imali dva vanredna ublažavanja kazne. Uz to, lica osuđena na kaznu zatvora ili doživotnog zatvora za dela za koja je zabranjen uslovni otpust ni sada nisu lišena prava na podnošenje zahteva za ponavljanje postupka zbog novih činjenica ili novih dokaza kojih nije bilo kada je izricana kazna ili sud za njih nije znao iako su postojali, a oni bi očigledno doveli do blaže krivične sankcije. Dakle, ne postoji zabrana izricanja, u ponovljenom krivičnom postupku, blaže kazne licima osuđenim na kaznu zatvora ili doživotnog zatvora za dela za koja je zabranjen uslovni otpust, ako se steknu uslovi propisani navedenom odredbom.

3) U samom nazivu „novog” pravnog leka ali i u pojmu vanrednog ublažavanja kazne je naknadno ispitivanje izrečene kazne i izricanje blaže kazne. Suštinski je isto određenje i u odredbi člana 473 stav 1 tačka 6 ZKP. Dakle, postojeća kazna se ublažava ili zamenjuje blažom kaznom. Ukoliko bi se kazna doživotnog zatvora ublažila (ostala ista ali u kraćem trajanju) onda bi nova osuda glasila, besmisleno, na polovinu ili dve trećine doživotnog zatvora. Ukoliko bi se zamenila blažom kaznom onda bi osuda morala glasiti na maksimalnih 20 godina zatvora. Ni jedno od ovih rešenja nije prihvatljivo.

4) Penološki razlozi koji bi po predloženom zaključku bili osnov zahteva za vanredno ublažavanje kazne su već sadržani u institutu uslovnog otpusta, članu 46 stav $1 \mathrm{KZ}$. Neprihvatljivo je da se isti osnov, već postojeći, uvede i u predloženi nov institut. Penološki razlozi nisu osnov izmene kazne, niti njenog ublažavanja. Kazna ostaje ista a osuđeni iz penoloških razloga stiče beneficije.

5) Predlog uslova primene predloženog zahteva za vanredno ublažavanje kazne je neprihvatljiv. Osuđeni na kaznu zatvora za krivična dela za koja nije dozvoljen uslovni otpust bi zahtev za vanredno ublažavanje kazne mogao podneti posle 25 godina izdržane kazne zatvora. Međutim osuđeni na kaznu doživotnog zatvora za delo za koje nije zabranje uslovni otpust prema odredbi člana 46 stav 2 prva alineja, pravo na uslovni otpust stiče protekom 27 godina iz- 
držane kazne zatvora. Dakle, osuđeni na „kvalifikovan” doživotni zatvor bio bi beneficiran u odnosu na osuđenog na „običan” doživotni zatvor. Takođe bi bio beneficiran i u odnosu na aktuelne osuđenike na kaznu zatvora u trajanju od 40 godina, koji uslovni otpust mogu tražiti po proteku 26,6 godina izdržane kazne zatvora. Da je ostala važeća kazna zatvora u trajanju od 40 godina to bi bila teža kazna od kazne doživotnog zatvora za dela za koja je uslovni otpust isključen, pa bi se branioci zalagali za kaznu doživotnog zatvora a ne kaznu zatvora u trajanju od 40 godina, jer se pre stiče pravo na uslovni otpust. Kod postojećeg stanja zakonodavstva i predloženim izmenama, osuđeni na kaznu doživotnog zatvora, sada bez prava na uslovni otpust, bi posle 25 godina izdržane kazne zatvora podneo zahtev, pa ako su ispunjeni uslovi, kazna bi mu bila zamenjena kaznom zatvora u trajanju od maksimalnih 20 godina zatvora. Osuđeni bi u tom slučaju, uslovno rečeno, više „preležao” 5 godina zatvora, pa bi stekao pravo i na naknadu štete.

6) Pod predloženim uslovima kazna doživotnog zatvora bi se delila na lakši i teži doživotni zatvor.

7) Neprihvatljivo je da se samo za jednu kaznu uvodi jedan, poseban, vanredni pravni lek.

8) Razlozi pri kraju tačke b. da se novi pravni lek uvodi zbog nemogućnosti korišćenja postojećih, je logički neprihvatljiv. Umesto uvođenja novog pravnog leka zbog nemogućnosti, bolje je otvoriti mogućnost.

9) Smeštanjem ovog pravnog leka u procesno zakonodavstvo, onako kako je predloženo, narušio bi se sistem krivičnog zakonodavstva. Kod ocene ispunjenosti uslova za primenu ovog pravnog leka, konkretno za uslovni otpust osuđenog lica za delo iz člana 46 stav $5 \mathrm{KZ}$ primenjivao bi se ZKP, dok bi se za ostale osuđenike. na ocenu ispunjenosti uslova za uslovni otpust, primena ovog instituta nužno naslanjala ne odredbe KZ.

10) Sve i da se u ZKP uvede predloženi pravni lek morao bi se izmeniti i KZ, bar odredba člana 46 stav $5 \mathrm{KZ}$ kako bi bilo moguće da se, za u toj odredbi navedena krivična dela, primeni uslovni otpust. Zato je nelogičan i pravno neodrživ navod predloženog zaključka, na samom početku ,zadržati postojeće odredbe Krivičnog zakonika o kazni doživotnog zatvora...”

11) U predloženom zaključku se navodi ,uvođenje novog vanrednog pravnog leka - Zahteva za vanredno ublažavanje kazne..." Već je rečeno da bi se nužno morala izmeniti (bar brisati) odredba člana 46 stav $5 \mathrm{KZ}$ kako bi za navede- 
na krivična dela uslovni otpust bio moguć, odnosno otklonjena zabrana uslovnog otpusta. U Srbiji je već doneta prva prvostepena presuda kojom je učinilac osuđen na kaznu doživotnog zatvora za delo za koje uslovni otpust nije dozvoljen. Izmenjeni KZ bi za osuđenog bio blaži, povoljniji. Samo teorijski: „Primena novog blažeg zakona nije moguća u postupku vanrednog ublažavanja kazne". (Pravno shvatanje Krivičnog odeljenja Vrhovnog suda Srbije od 26. decembra 1994. godine). Identičan stav se primenjuje i kod ponavljanja krivičnog postupka.

\section{Obaveza preispitivanja kazne - pravo na nadu}

Stavovi ECHR su jasni. Kazna doživotnog zatvora nije suprotna Evropskoj konvenciji o zaštiti ljudskih prava i osnovnih sloboda, niti je u suprotnosti sa praksom ECHR. Kaznu doživotnog zatvora, da bi ispunila prethodna dva uslova njene dozvoljenosti, mora de iure i de facto da prati mogućnost da osuđeni bude pušten na slobodu, mora biti smanjiva. Isto važi i za zatvorske kazne za navedena krivična dela. Mora postojati, kako normativna, tako i realna mogućnost preispitivanja trajanja kazne i na legitimnim penološkim razlozima zasnovana nada da će osuđeni biti pušten na slobodu ukoliko se tokom trajanja zatvora ispuni svrha kažnjavanja i kazna prestane da bude opravdana. Opšti penološki cilj je na rehabilitaciji a ne na represiji. Ukoliko je zabranjen uslovni otpust, kazna doživotnog zatvora gubi svrhu rehabilitacije i predstavlja isključivo represiju. Zatvorskim ustanovama se oduzima ,šargarepa”, jedno od sredstava za odbranu od destruktivnog ponašanja ovih osuđenika, odnosno zaštite bezbednosti u tim zavodima. U stručnoj literaturi je većinski stav da kazna doživotnog zatvora, posebno kada ne postoji mogućnost preispitivanja njenog trajanja, predstavlja odloženu smrtnu kaznu,odnosno civilnu smrt.

Izostavljanjem mogućnosti puštanja na uslovni otpust osuđenih na kaznu doživotnog zatvora povređuje se pravo na nadu osuđenih lica, kao i pravo na ljudsko dostojanstvo. Kršenje prava na nadu osuđenih na kaznu doživotnog zatvora za krivična dela za koja uslovni otpust nije dozvoljen često se shvata kao floskula, jer je u podsvesti težina dela za koje su učinioci osuđeni. Da bi to pravo približili realnosti razmotrimo da li pravo na nadu imaju bolesni od neizlečivih bolesti ili njihovo lečenje zbog toga treba prekinuti ili da li decu sa mentalnim invaliditetom ne treba obrazovati jer je domet obrazovanja ograničen ili im osnovano dati pravo na nadu da će biti izlečeni ili da će granica u obrazovanju biti pomerena. 


\section{Drugačiji stavovi}

Ima zagovornika, doduše usamljenih, da je pomilovanje dovoljan institut za preispitivanje kazne doživotnog zatvora, da obezbeđuje pravo na nadu licima osuđenim na kaznu doživotnog zatvora bez prava na uslovni otpust. Zagovornici ovog rešenja potporu za svoj stav nalaze u uporedno pravnim zakonodavnim rešenjima i stavu ECHR da je pomilovanje u nekim od zemalja delotvoran pravni lek. Ne u svim. Da bi pomilovanje bilo ocenjeno kao delotvoran pravni lek neophodna je analiza ukupnog pravnog sistema pojedinih zemalja, uključujući i pravnu tradiciju kao i u praksi potvrđene delotvornosti pomilovanja. Navedeni stav ne smatramo prihvatljivim u našem pravnom sistemu.

Odluka o ispunjenim penološkim uslovima predstavlja deo kaznene politike, posmatrane kao celine. Uslovni otpust predstavlja sudski odgovor na delotvornost $\mathrm{u}$ sudskom postupku izrečene kazne, na postignutu svrhu kažnjavanja. Takođe, u postupku primene uslovnog otpusta je obezbeđena dvostepenost u odlučivanju. Pomilovanje predstavlja vansudski odgovor.

Čini se da je besmisleno u krivičnom, sudskom postupku propisati zabranu uslovnog otpusta, potpuno zanemariti postignutu svrhu kažnjavanja a dozvoliti pomilovanje zbog postignute svrhe kažnjavanja.

Uslov da propisana kazna doživotnog zatvora bude saglasna Konvenciji i praksi ECHR je i da predviđeni pravni lek i de facto pruža mogućnost da osuđeni, kod ispunjenih uslova, bude pušten na slobodu. Postupak mora pružiti dovoljno garancija da je pravni lek delotvoran, primenljiv u praksi. Pomilovanje u našem zakonodavstvu taj uslov neće ispuniti. Predsedničko pomilovanje ni u odredbama Krivičnog zakonika ni u Zakonu o pomilovanju ne predviđa uslove, razloge, za davanje pomilovanja. Zato nije ispunjen ni uslov, zahtev, da unapred, odnosno već u trenutku presuđenja, osuđenom licu budu poznati zakonom predviđeni uslovi puštanja na slobodu. U suprotnom, ako domaće zakonodavstvo ne obezbeđuje nijedan mehanizam ili mogućnost preispitivanja kazne doživotnog zatvora, neusaglašenost te kazne sa članom 3 Evropske povelje po ovom osnovu se pojavljuje već u trenutku njenog izricanja, a ne u trenutku njenog izdržavanja. Za ocenu delotvornosti pomilovanja kod nas dovoljno je navesti da je od 2013. godine do 2018. godine Predsednik Republike odlučivao o 127 molbi za pomilovanje osuđenih na kaznu zatvora u trajanju od 15 godina zatvora ili težu kaznu i da ni jedna nije uvažena (Ilić, 2019:130).

Zakon o pomilovanju bi naravno morao biti temeljno izmenjen da bi se uopšte razmatrala mogućnost ocene ovog instituta kao delotvornog pravnog leka. Te izmene mora pratiti i izmena KZ. Zakonom o pomilovanju je predviđeno 
da se pomilovanje daje u skladu sa krivičnim zakonom, sada KZ. Ovakvo zakonodavno rešenje nameće potrebu izmene KZ i uklanjanje zabrane uslovnog otpusta za navedena krivična dela, odnosno otvaranje mogućnosti puštanja na uslovni otpust, jer u suprotnom pomilovanje ne da ne bi bilo u skladu sa Krivičnim zakonikom, već suprotno njemu. Time dolazimo na isto, odnosno na neophodnost brisanja zabrane uslovnog otpusta za navedena krivična dela, kako bi pomilovanje moglo bilti dato. U tom slučaju bi bila dovoljna primena $\mathrm{KZ}$ da bi bili ispunjeni uslovi Konvencije i prakse ECHR.

Sporno je i što zakon o pomilovanju ne predviđa mogućnost preispitivanja odluke o pomilovanju, dvostepenost, iako se njome odlučuje o pravima trećih lica.

\section{Zaključak}

Verovatno je svima jasno da je najbolje rešenje ono najednostavnije: brisati zabranu uslovnog otpusta za krivična dela za koja je zabrana propisana. Traženje drugih rešenja nije ništa drugo nego li izbegavanje priznanja da se prenaglilo sa sadašnjim zakonodavnim rešenjem. Druga, zaobilazna, rešenja mrežu zakona čine razvučenom i slabom. Moguće rešenje je da se osuđenim licima za ova krivična dela, ukoliko budu uslovno otpuštena, uz uslovni otpust odredi dugotrajna, pa i doživotna, odgovarajuća mera bezbednosti, kao zaštita od mogućeg recidiva. Ovim stavom se opredeljujemo za zaključak predložen pod a) tačke 4, uz opasku da isti ne može biti ograničen samo na kaznu doživotnog zatvora, već se mora odnositi i na zatvorske kazne za dela navedena u članu 46 stav $5 \mathrm{KZ}$. Ukoliko bi se izmena odnosila samo na kaznu doživotnog zatvora, kako je u zaključku predloženo, onda bi osuđenici na zatvorsku kaznu, primera radi u trajanju od 20 godina, ostali bez prava na uslovni otpust, što bi takođe bilo protivno Evropskoj konvenciji o ljudskim pravima i praksi Evropskog suda.

Predlog da osuđeni na kaznu doživotnog zatvora za krivična dela za koja sada uslovni otpust nije dozvoljen, to pravo stekne protekom 25 godina računajući od početka izdržavanja kazne, zasnovan je na presudi Evropskog suda Vinter i drugi protiv Ujedinjenog Kraljevstva (odluka od 9. jula 2013. godine) u kojoj se navodi da je nužno da nacionalna zakonodavstva predvide mehanizam preispitivanja opravdanosti penološkim razlozima nastavka izdržavanja kazne i to ne duže od 25 godina, računajući od početka izdržavanja kazne. Ukoliko bi se predlog usvojio a zadržala postojeća rešenja u KZ, dolazimo u situaciju izloženu pod tačkom 5 ovog rada, odnosno da se pravo na uslovni otpust osuđenih na kazne doživotnog zatvora stiče posle 25 ili posle 27 godina a za kaznu zatvora 
u trajanju od 40 godina posle 26,6 godina, sve računajući od početka izdržavanja kazne. Ne postoje kriminalno politički razlozi za ove razlike, niti je sticanje prava na uslovni otpust protekom 27 godina ili 26,6 godina u skladu sa odlukom Evropskog suda. Zato, ukoliko se pristupi izmenama krivičnog zakonodavstva opravdano bi bilo da se za sve ove kazne propiše pravo na sticanje uslovno otpusta protekom jedinstvenog roka od 25 godina, računajući od početka izdržavanja kazne zatvora.

Konačno, izmena Krivičnog zakonika u delu koji je predmet ovog rada je neophodna i ne mora se čekati odluka Ustavnog suda Srbije ili Evrpskog suda za ljudska prava da bi se izmene njima pravdale. Posebno što ovo nije jedini propust zakonodavca u Krivičnom zakoniku (primera radi videti odredbu o višestrukom povratu, koja za razliku od odredbe o običnom povratu ili za razliku od odredbe o kazni doživotnog zatvora ne sadrži deo ,izuzev kada zakon predviđa da se kazna može ublažiti ili da se učinilac može osloboditi od kazne") pa bi to bila prilika i za otklanjanje i drugih propusta.

\section{Literatura}

- Dimovski, D., Vujačić, M., Jovanović, M., (2019) Doživotna kazna zatvora zakonodavstvo Srbije i međunarodni standardi. Pravna riječ, 60.

- Ilić, G. (2019). Marginalije o kazni doživotnog zatvora, uslovnom otpustu i ljudskim pravima. U: Ignjatović, Đ (ur.) Kaznena reakcija u Srbiji, ()123-142. Beograd: Univerzitet u Beogradu, Pravni fakultet.

- Jocić, D. (2020) Odgovornost za teže oblike krivičnih dela. (u pripremi)

- Radulović, D. (2020) Dugotrajni ili doživotni zatvor. Revija za kriminologiju $i$ krivično pravo, $58(1$ i 2), str. 69-87. https://doi.org/10.47152/rkkp.58.1.2.4 
Dragan JOCIĆ

President of the Court of Appeal in Nis, Jugde of the Supreme Court of Cassation

\section{CONTRIBUTION TO THE DEBATE ON THE SENTENCE OF LIFE IMPRISONMENT AND INTERNATIONAL LEGAL STANDARDS}

The latest amendments to the Criminal Code of the Republic of Serbia have quite a lot of controversy among the professional public. The subject of this paper is a critical review of various propositions for overcoming legislative omissions in relation to the sentence of life imprisonment without conditional release for certain criminal offences. Furthermore, this paper deals with prison sentences for crimes for which the conditional release is legally excluded. The intention is to encourage the professional public to find the best solutions for overcoming legally untenable prohibition of conditional release for people sentenced to life imprisonment. The author estimates that pardon, in our legislation, does not represent an effective legal remedy, nor an alternative to conditional release.

Keywords: life imprisonment, conditional release, motion for an extraordinary reduction of sentence, pardon. 